\title{
Histopatologi Bronkiolus dan Pembuluh Darah Paru Mencit Jantan Pasca Terpapar Asap Rokok Elektrik
}

\author{
(HISTOPATOLOGYCAL BRONKIOLUS AND BLOOD VESSEL OF MICE LUNG POST \\ EXPOSURE OF ELECTRIC CIGARETTE SMOKE)
}

\author{
Mia Monica ${ }^{1 *}$, Anak Agung Ayu Mirah $\mathrm{Adi}^{2}$, Ida Bagus Oka Winaya ${ }^{2}$ \\ ${ }^{1}$ Perum Podomoro, B2-05, Sukorame, Kediri, Jawa Timur, Indonesia 64144; \\ ${ }^{2}$ Laboratorium Patologi Veteriner, Fakultas Kedokteran Hewan, Universitas Udayana, Jl. PB. \\ Sudirman Denpasar Bali, Indonesia 80225. \\ *Email: mia.monica96@gmail.com
}

\begin{abstract}
ABSTRAK
Penelitian ini bertujuan untuk mengetahui perubahan histopatologi bronkiolus dan pembuluh darah paru mencit (Mus musculus) jantan pasca terpapar asap rokok elektrik (vaping). Penelitian menggunakan 24 ekor mencit yang dibagi menjadi dua kelompok perlakuan. Kelompok I (P0) sebagai kelompok kontrol yakni tanpa perlakuan pemaparan asap rokok elektronik dan kelompok II (P1) yang terdiri dari 12 ekor mencit sebagai kelompok perlakuan yang diberi paparan asap rokok elektrik. Penelitian ini menggunakan rancangan acak lengkap (RAL) pola split in time dengan tiga kali pengambilan sampel minggu ke $-1,-2$ dan -3 pasca perlakuan. Masing-masing kelompok diambil 4 ekor mencit pada setiap waktu pengamatan. Jaringan paru diambil untuk dibuat preparat dan diwarnai dengan pewarnaan Hematoksilin-Eosin (HE). Hasil penelitian menunjukkan terdapat perbedaan yang signifikan $(\mathrm{P}<0,05)$ antara kelompok perlakuan dan kelompok kontrol, namun lama paparan tidak berpengaruh. Ketebalan mukosa pada kelompok perlakuan lebih tinggi dibandingkan kelompok kontrol $(\mathrm{P}<0,05)$. Pembuluh darah paru terjadi endotheliosis dan thrombosis. Dapat disimpulkan, paparan asap rokok elektrik dapat menimbulkan degenerasi, nekrosis sel dan meningkatkan ketebalan mukosa bronkiolus. Sistem vaskuler mengalami endotheliosis, nekrosis sel endotel serta thrombosis.
\end{abstract}

Kata kunci: mencit; bronkiolus; pembuluh darah paru; rokok elektrik

\begin{abstract}
This study aim was to determine the histopathological changes of bronchioles and blood vessel of mice (Mus musculus) lung post exposed of electric cigarette smoke (vaping). This study was used 24 mice that were divided into two treatment groups. Group I (P0) as a control without electronic cigarette smoke exposured and group II (P1) consistied of 12 mice as a treatment group, were exprosure with electric cigarette smoke. This study used a complete randomized design (RAL) split in time pattern with three 1st, 2nd and 3rd post-treatment sampling times. A four mice of each group was taken at each observation time. Lung tissue was taken to make preparations and stained with Hematoxilin-eosin (HE) staining. The results showed that there were significant differences $(\mathrm{P}<0.05)$ between the treatment group and the control group, but the duration of exposure did not have an effect. Mucosal thickness in the treatment group was higher than in the control group $(\mathrm{P}<0.05)$. Vessel lung endotheliosis and thrombosis. It can be concluded, exposure to electric cigarette smoke can cause degeneration, cell necrosis and increase mucosal thickness of the bronchioles. The vascular system experiences endotheliosis, endothelial cell necrosis and thrombosis.
\end{abstract}

Keywords: mice; bronchioles; lung vessels; electric cigarette 


\section{PENDAHULUAN}

Perilaku merokok merupakan masalah kesehatan dunia, karena menyebabkan berbagai penyakit dan menyebabkan kematian (Chodijah,2012). Telah diinformasikan bahwa setiap delapan detik satu orang meninggal karena rokok. Namun demikian, jumlah perokok di negara berkembang terus meningkat walaupun di negara maju telah mengalami penurunan (Muliartha et al., 2009). Menurut lembaga survey WHO tahun 2008, Indonesia menduduki peringkat ke 3 sebagai jumlah perokok terbesar di dunia, dan kini Indonesia juga mencetak rekor baru, yakni jumlah perokok remaja tertinggi di dunia (Fikriyah et al., 2012).

Hingga saat ini, WHO terus mendorong masyarakat agar berhenti merokok untuk mengurangi bahaya tembakau dengan berbagai metode, salah satunya adalah menggunakan Nicotine Replacement Therapy (NRT) yaitu terapi pengganti nikotin (WHO, 2009). Electronic cigarette (rokok elektronik) atau e-cigarette merupakan salah satu NRT yang menggunakan listrik dari tenaga baterai untuk memberikan nikotin dalam bentuk uap dan oleh WHO disebut sebagai Electronic Nicotine Delivery System (Tanuwiharja dan Susanto, 2012). Rokok elektronik mengandung cairan yang berbeda-beda, namun pada umumnya berisi larutan terdiri dari 4 jenis campuran yaitu nikotin, propilen glikol, gliserin, air dan flavoring (perisa) (William et al., 2010). Nikotin adalah zat yang sangat adiktif yang dapat merangsang sistem saraf, meningkatkan denyut jantung, tekanan darah, penyempitan pembuluh darah tepi, dan menyebabkan ketagihan dan ketergantungan pada pemakainya (Hasanah, 2014). Selain itu nikotin bersifat karsinogenik yang dapat menyebabkan gangguan kesehatan, salah satunya adalah penyakit kanker paru-paru (Triana et al., 2013). Sedangkan Roomans et al. (2002) dalam penelitiannya membuktikan bahwa nikotin dapat menyebabkan perubahan homeostasis epitel paru-paru dan meningkatkan reaksi inflamasi. Propilen glikol adalah zat dalam kepulan asap buatan yang biasanya di acara-acara panggung teatrikal, atau juga digunakan sebagai antifrezee, pelarut obat dan pengawet makanan. Zat ini jika dihirup menyebabkan iritasi pernapasan, dan secara kronis menyebabkan asma, mengi (wheezing), sesak dada, penurunan fungsi paru-paru, dan obstruksi jalan pernapasan (InfoPOM, 2015).

Rokok tidak hanya berbahaya bagi perokok itu sendiri, melainkan orang-orang disekitarnya yang menghirup asap rokok (Sary dan Nuryani, 2014). Selain itu asap rokok berbahaya bagi hewan peliharaan apabila terpapar oleh asap rokok. Hal ini dibuktikan oleh penelitian yang dilakukan Bertone et al. (2002) yang melaporkan bahwa asap rokok (perokok pasif) dapat meningkatkan risiko terjadinya limfoma ganas pada kucing.

Rokok elektrik dengan kandungan nikotin, propilen glikol, gliserin, air dan flavoring (perisa) yang dapat menyebabkan perubahan struktur, fungsi saluran napas dan jaringan paru-paru. Nikotin dalam jangka waktu lama akan terakumulasi dalam pembuluh darah dan mengakibatkan terjadinya penyempitan dinding pembuluh darah (Gilman et al., 1991). Masih terbatasnya informasi mengenai pengaruh paparan asap rokok elektrik pada saluran pernafasan secara histopatologi, khususnya pada bronkiolus dan pembuluh darah paru, maka perlu diteliti untuk mengetahui gambaran histopatologi bronkiolus dan pembuluh darah paru mencit (Mus musculus) jantan setelah dipapari asap rokok elektrik (Vaping).

\section{METODE PENELITIAN}

Penelitian ini menggunakan 24 ekor mencit (Mus musculus) jantan berumur 22,5 bulan dan berat badan 18-20 gr yang didapatkan di Kota Denpasar, Provinsi Bali. Percobaan menggunakan 24 ekor mencit yang dibagi menjadi dua kelompok perlakuan secara acak. Kelompok I (P0) sebagai kelompok kontrol yakni tanpa 
perlakuan pemaparan asap rokok elektronik dan kelompok II (P1) yang terdiri dari 12 ekor mencit sebagai kelompok perlakuan yang diberi paparan asap rokok elektrik. Ruang pemaparan asap rokok elektrik menggunakan kardus yang sudah dimodifikasi. Dimana kardus tersebut diberi pembatas agar tidak terjadi stress pada mencit yang berbeda kelompok apabila disatukan. Proses pemaparan dilakukan dengan meniupkan rokok elektrik ke dalam kardus, sehingga asap memenuhi kardus yang kemudian ditutup selama 30 menit. Pengamatan dilakukan sebanyak tiga kali yakni minggu ke $-1,-2$ dan -3 pasca perlakuan. Penelitian ini menggunakan rancangan acak lengkap (RAL) pola Split in Time (3 kali waktu pengamatan). Dimana untuk masing-masing kelompok dikorbankan 4 ekor mencit pada setiap waktu pengamatan. Mencit (Mus musculus) kemudian diterminasi dengan cara dislokasi leher kemudian dinekropsi sesuai prosedur, kemudian diambil jaringan paru dan dimasukkan ke dalam tabung jaringan yang telah berisi larutan NBF 10\%. Selanjutnya sampel jaringan paru diwarnai dengan pewarnaan Harris-Hematoxylin-Eosin (HE). Variabel yang diamati meliputi degenerasi, nekrosis, dan ketebalan mukosa pada epitel mukosa bronkiolus. Pada pembuluh darah paru diamati kongesti, thrombosis, endotheliosis dan nekrosis endotel.

\section{HASIL DAN PEMBAHASAN}

Hasil pemeriksaan histolpatologi pada bronkiolus menunjukkan pada perlakuan kontrol mukosa bronkiolus masih mulus, epitel tidak ada yang nekrosis. Pada kelompok perlakuan terdapat degenerasi dan nekrosis pada mukosa bronkiolus. Dari hasil analisis data dengan uji Man-Whitney di dapatkan bahwa terdapat perbedaan yang signifikan antara kelompok perlakuan dan kelompok kontrol. Dimana hasil uji MannWhitney rerata skor perubahan degenerasi dan nekrosis antara kelompok perlakuan dan kelompok kontrol menunjukkan perbedaan yang signifikan $\mathrm{P}<0,05)$. Sedangkan jika dibandingkan rerata nilai skoring gambaran perubahan degenerasi dan nekrosis pada kelompok perlakuan yang diamati pada minggu pertama, kedua, dan ketiga tidak ditemukan perbedaan yang signifikan $(\mathrm{P}>0,05)$, ini artinya jarak waktu pengamatan belum dapat menimbulkan perubahan yang signifikan.

Gambaran histopatologik akibat paparan asap rokok elektrik (vaping) pada bronkiolus dapat dilihat dibawah ini pada Gambar 1, 2, dan 3.

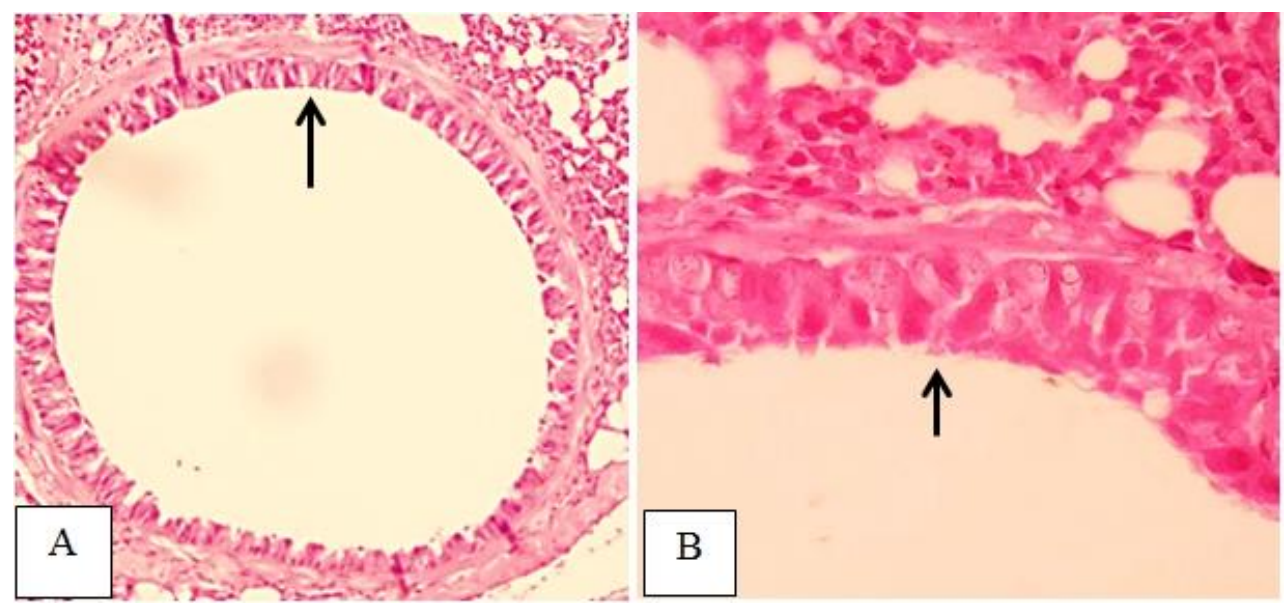

Gambar 1. Histopatologi bronkiolus kelompok kontrol minggu ke-1 (A: HE,200x, B: HE,400x). Ket. Epitel mukosa masih tampak normal (tanda panah) 


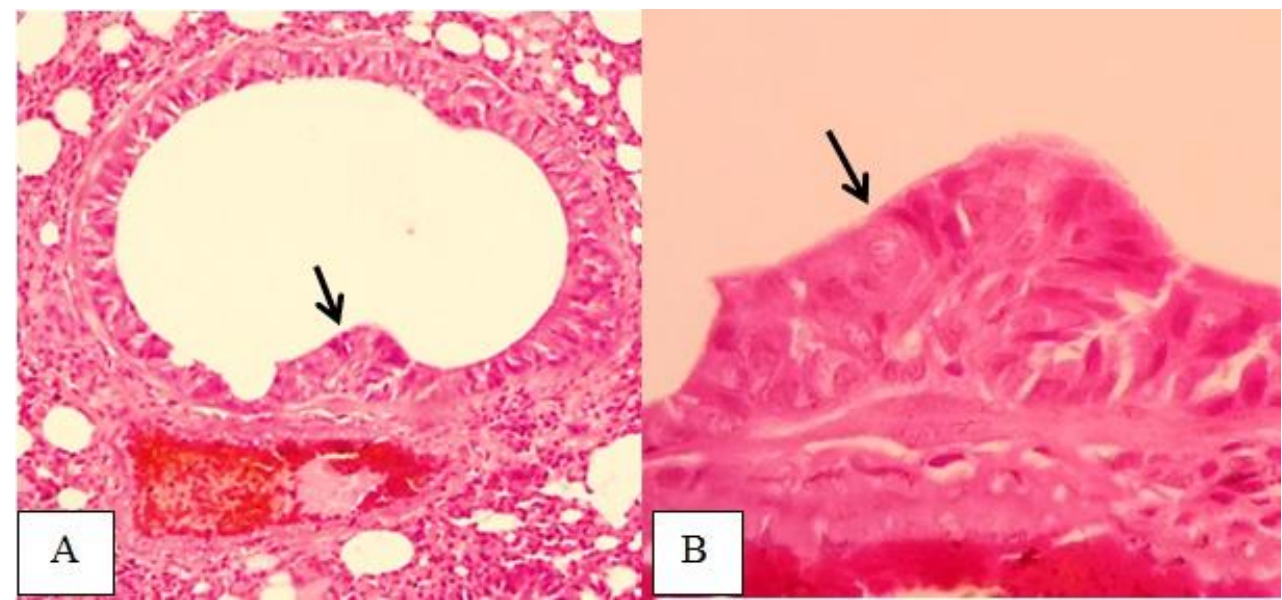

Gambar 2. Histopatologi bronkiolus 1 minggu pasca perlakuan (A: HE,200x, B: HE,400x). Ket. mengalami degenerasi pada epitel mukosa sehingga terjadi pembengkakan mukosa (tanda panah).

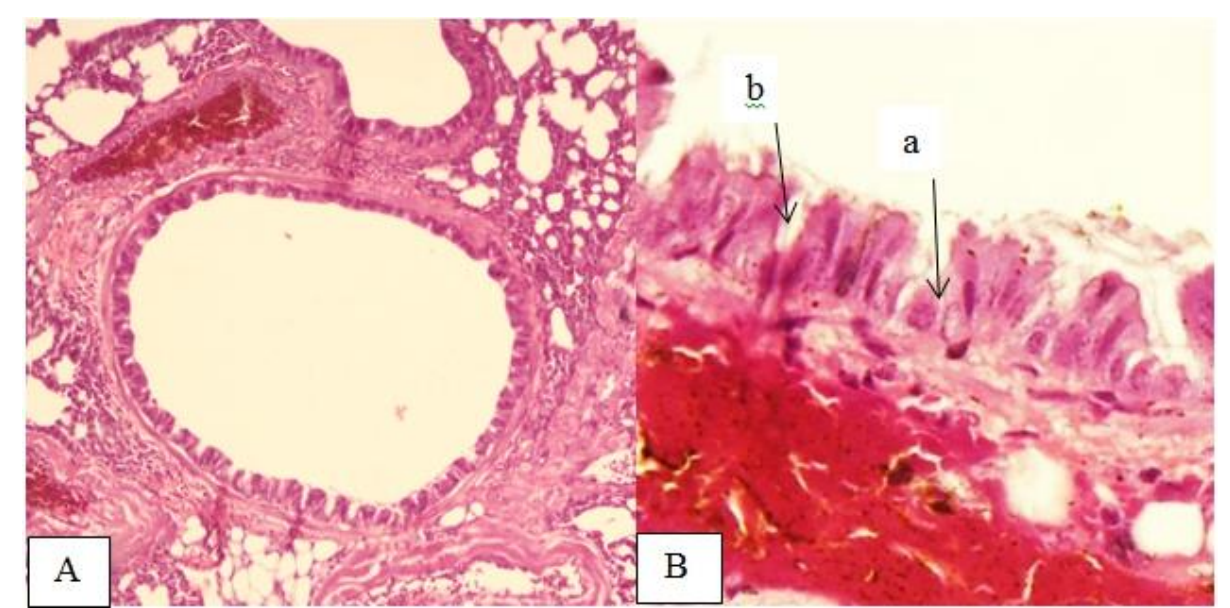

Gambar 3. Histopatologi bronkiolus mencit 2 minggu pasca perlakuan (A: HE,200x, B: HE, 400x). Ket (a) mengalami degenerasi (b) mengalami nekrosis

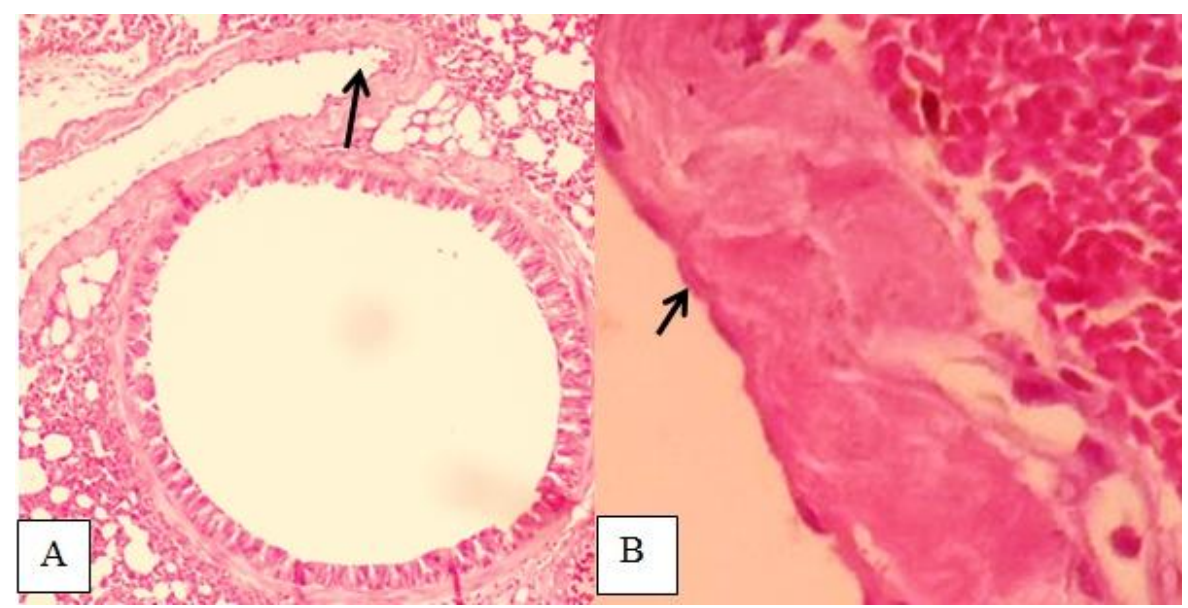

Gambar 4. Histopatologi pembuluh darah paru mencit kontrol minggu ke- 1 (A: HE,200x, B: HE, 400x). Ket. endotel masih dalam batas-batas normal (tanda panah) 


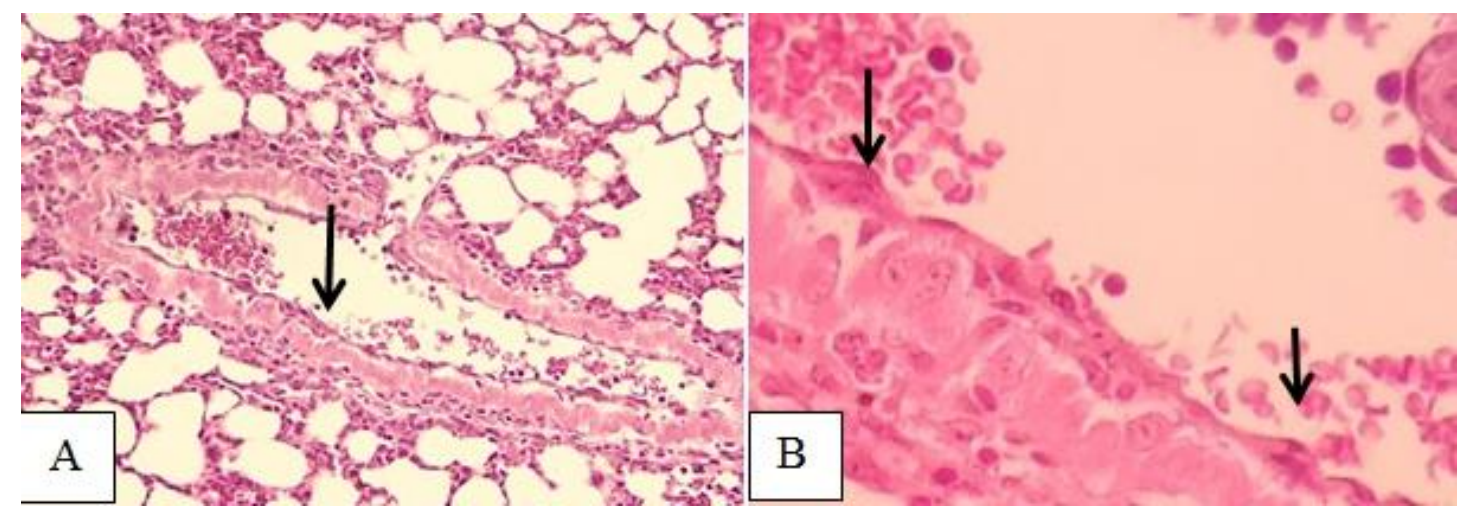

Gambar 5. Histopatogi pembuluh darah paru mencit 1 minggu pasca perlakuan (A: HE,200x, B: HE, 400x). Ket. mengalami endotheliosis sehingga endotel tampak bertumpuk (tanda panah)

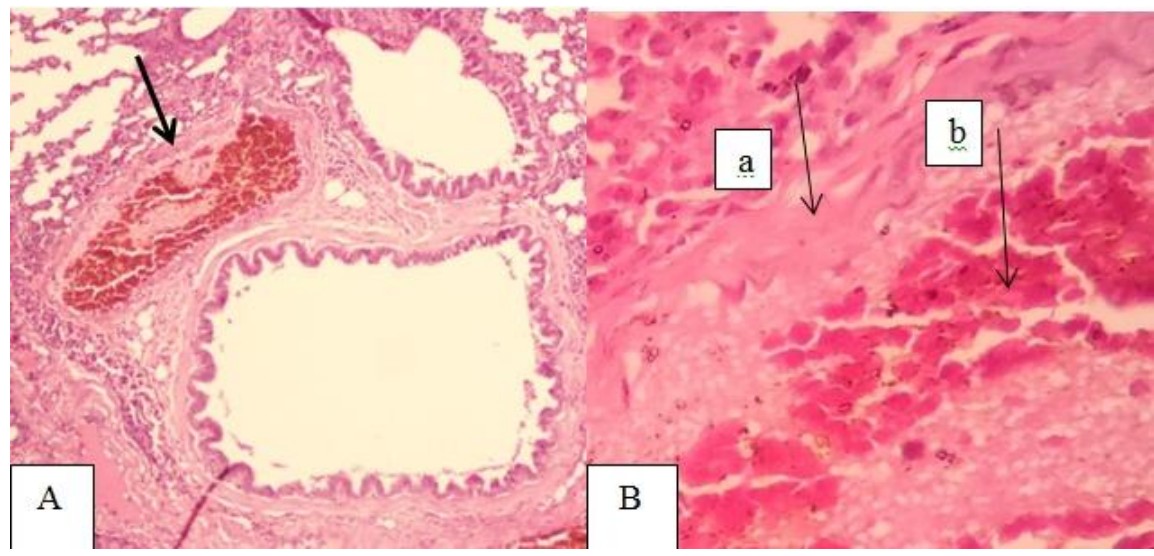

Gambar 6. Histopatologi pembuluh darah paru mencit 3 minggu pasca perlakuan (A:

HE, 200x, B: HE, 400x). Ket (a) nekrosis endotel dan (b) mengalami thrombosis

Hasil pemeriksaan histologipatologi pembuluh darah paru ditemukan kongesti, thrombosis, endotheliosis dan nekrosis pada endotel. Pada perlakuan kontrol minggu pertama secara histopatologi tidak ditemukan perubahan, endotel masih dalam batas-batas normal. Sedangkan, pada perlakuan minggu pertama terlihat endotheliosis yakni sel nampak bertumpuk. Gambaran perubahan histopatologis akibat paparan asap rokok elektrik (vaping) pada pembuluh darah paru dapat dilihat pada Gambar 4, 5, dan 6.

Hasil uji Univariate menunjukkan bahwa rerata ketebalan mukosa pada kelompok perlakuan lebih tinggi dibandingkan kelompok kontrol $(\mathrm{P}<0,05)$. Sedangkan Hasil dari pengukuran ketebalan mukosa yang dianalisis dengan uji Quadratic diperoleh ketebalan mukosa dengan lama waktu paparan tidak signifikan $(\mathrm{P}>0,05)$.

Rokok elektronik mengandung cairan yang berbeda-beda, namun pada umumnya berisi larutan terdiri dari empat jenis campuran yaitu nikotin, propilen glikol, gliserin, air dan flavoring (perisa) (William et al., 2010). Sedangkan, nikotin adalah zat yang sangat adiktif yang dapat merangsang sistem saraf, meningkatkan denyut jantung, tekanan darah, penyempitan pembuluh darah tepi, dan menyebabkan ketagihan dan ketergantungan pada pemakainya (Hasanah, 2014). Selain itu nikotin bersifat karsinogenik yang dapat menyebabkan gangguan kesehatan, salah satunya adalah penyakit kanker paru-paru (Triana et al., 2013). Sedangkan Roomans et al. (2002) 
dalam penelitiannya membuktikan bahwa nikotin dapat menyebabkan perubahan homeostasis epitel paru-paru dan meningkatkan reaksi inflamasi. Inflamasi saluran pernapasan mengakibatkan dilepaskannya beberapa macam mediator yang dapat mengaktivasi sel target di saluran napas. Kerusakan epitel pada saluran pernapasan terjadi karena adanya mediator inflamasi yaitu eosinophil yang dilepaskan pada saat proses inflamasi, kebocoran mikrovaskular, hipersekresi mukus, dan adanya radikal bebas reaktif akibat aktivasi sel dan pelepasan mediator inflamasi yang merusak membran biologis penyusun sel-sel epitel (Supartini et al., 1995).

Gambaran mikroskopis berupa degenerasi dan nekrosis berbeda nyata $(\mathrm{P}<0,05)$ ditemukan pada kelompok perlakuan dibandingkan dengan kelompok kontrol. Dimana pada kelompok kontrol tidak ditemukan degenerasi dan nekrosis. Hal ini sesuai dengan pernyataan Marianti (2009) mengatakan paru-paru yang tidak terpapar dengan toksikan yang terkandung dalam asap rokok, pada sel-selnya tidak mengalami kerusakan. Sedangkan, pada perlakuan pemaparan asap rokok elektrik yang dilakukan berdampak pada perubahan struktur histologi bronkiolus seperti degenerasi dan nekrosis pada epitel mukosa, hal ini sesuai dengan penelitian dari Triana et al. (2013) yang menyatakan paparan asap rokok secara kontinyu dapat menyebabkan kerusakan mikroanatomi paru-paru. Hal ini disebabkan telah terjadi perusakan sel-sel epitelium dan endotelium pada alveolus oleh toksikan pada asap rokok. Palmans et al. (2002) menunjukkan bahwa paparan secara berkelanjutan dan terus-menerus dapat merangsang terjadinya inflamasi pada saluran pernapasan yang berakibat terjadinya remodeling jalan napas berupa terjadinya kerusakan epitel. Kerusakan epitel tersebut ditandai dengan adanya perubahan struktur epitel.

Asap rokok banyak mengandung radikal bebas diantaranya Hidroperoxida, Co2-, C, Peroxy, $\mathrm{O}_{2-}, \mathrm{CuOx}$ dan $\mathrm{CuGeO}_{3}$.
Asap rokok yang masuk ke dalam tubuh secara inhalasi akan menyebabkan tandatanda iritasi paru-paru, selanjutnya partikelpartikel asap rokok dengan cepat diserap oleh paru-paru menuju ke peredaran darah (Herliansyah, 2001). Akibat dari paparan yang terus menerus menyebabkan tingginya kadar radikal bebas di sirkulasi darah. Tingginya radikal bebas di dalam sirkulasi darah dapat menimbulkan stress oksidatif. Stress oksidatif dapat memicu meningkatnya kejadian apoptosis yang ditandai adanya sel nekrosis (Demedts et al., 2006). Namun, sebelum terjadi nekrosis didahului oleh adanya pembengkakan pada sel yang disebut degenerasi (Robin et al., 2007). Berata et al. (2016) menyatakan bahwa nekrosis dapat terjadi karena adanya proses lanjutan dari degenerasi akibat paparan asap rokok yang terus menerus sehingga fragmentasi membrane sel menyebabkan kematian sel.

Nikotin, CO dan bahan lainnya dalam asap rokok terbukti merusak dinding pembuluh endotel (dinding dalam pembuluh darah) (Sianturi, 2003). Menurut Papathanasiou et al. (2014) apabila konsentrasi radikal bebas dalam darah terus meningkatkan karena paparan berlebihan dari faktor berbahaya seperti merokok, maka radikal bebas dalam darah tidak dapat diatur dan dapat menyebabkan mutasi berbahaya yang merusak sel-sel. Disamping itu jumlah besar radikal bebas yang terkandung dalam asap rokok dapat meningkatkan stres oksidatif, mengurangi bioavailabilitas nitrat oksida, gangguan vasodilatasi. Stress oksidatif menyebabkan berkurangnya nitrit oksida (NO) pada sel. Penurunan NO akan menyebabkan terjadinya disfungsi endotel (Lawrence, 2004).

Disfungsi endotel dapat dipicu oleh dua hal utama yaitu stres fisik dan zat-zat iritan. Disfungsi endotel juga dapat terjadi akibat paparan zat-zat toksik, salah satunya akibat paparan asap rokok (Packard and Libby, 2008). Hal ini sesuai dengan pernyataan Ross (1999), Merokok memicu terbentuknya radikal bebas, yang 
selanjutnya akan menimbulkan stress oksidatif, gangguan vasodilator dan pada gillirannya akan terjadi disfungsi endotel. Apabila terjadi kerusakan endotel maka endotel pembuluh darah yang tidak utuh akan memicu interaksi antara thrombosit dengan dinding pembuluh darah sehingga menyebabkan thrombosis (Japardi, 2002).

Pada pembuluh darah paru mencit pada kelompok perlakuan kontrol menunjukan adanya perubahan berupa kongesti. Hal ini dapat terjadi karena pada saat penelitian mencit yang digunakan bukan mencit SPF sehingga tidak menutup kemungkinan mencit tersebut terpapar benda asing atau mencit mengalami stres fisik. Kongesti merupakan reaksi patologis sebagai salah satu manifestasi terjadinya peradangan akibat jejas (Darjono et al., 2001). Patnaik (1992), menyatakan bahwa sel yang rusak akan mengeluarkan histamine, sehingga menyebabkan terjadinya dilatasi kapilerkapiler darah dan terjadi peningkatan arus lokal. Setelah jejas, terjadi dilatasi kapiler akibat rangsang vasodilator sehingga vaskularisasi pada lokasi jejas melebar dan berisi darah yang terbendung (kongesti) (Kumar et al., 2007).

Ketebalan mukosa kelompok perlakuan lebih tinggi disbanding kelompok $(\mathrm{P}<0,05)$. Hal ini sesuai dengan pernyataan Squier and Brogden (1991) bahwa penebalan epitel pada mukosa diduga merupakan respon fisiologis terhadap iritan. Penebalan lapisan epitel dapat disebabkan adanya kandungan alilpirokatekol yang memiliki antioksidan, sehingga tubuh memproduksi mukus dan terjadi penebalan mukus pada mukosa yang bersifat sitoprotektif (Majundar et al., 2002; Bhattacharya et al., 2007). Adi (2014) menyatakan pada saluran pernapasan terdapat silia dan mucus yang dihasilkan dari sel mangkok yang berfungsi sebagai sistem pertahanan sehingga bila mukosa tersebut terpapar asap rokok elektrik secara terus menerus maka akan mengeluarkan cairan/mukus. Ketebalan mukosa terhadap lama waktu paparan tidak berbeda nyata $(\mathrm{P}>0,05)$. Hal ini dapat disebabkan karena kurang lamanya waktu paparan asap rokok elektrik dan rendahnya kandungan nikotin yang diberikan sehingga mukosa tersebut kurang mengalami iritan. Epler (1992) menyatakan bahwa, berbagai faktor yang berpengaruh dalam timbulnya penyakit atau gangguan pada saluran pernapasan yaitu faktor meliputi ukuran partikel, bentuk konsentrasi, daya larut serta sifat kimiawi dan faktor individual meliputi mekanisme pertahanan paru, anatomi dan fisiologi saluran napas serta faktor imunologis. Penilaian paparan dapat dipertimbangkan dari sumber paparan, lamanya paparan dan paparan dari sumber lain.

\section{SIMPULAN}

Degenerasi dan nekrosis sel epitel mukosa bronkiolus ditemukan pada kelompok perlakuan. Paparan asap rokok elektrik (vaping) meningkatkan ketebalan mukosa dan menimbulkan endotheliosis, nekrosis sel endotel serta thrombosis.

\section{SARAN}

Perlu dilakukan penelitian lanjutan dengan waktu paparan asap rokok elektrik lebih lama untuk melihat perubahan yang lebih spesifik.

\section{UCAPAN TERIMA KASIH}

Penulis mengucapkan terima kasih terutama kepada semua pihak yang telah membantu dalam penyelesaian penelitian ini.

\section{DAFTAR PUSTAKA}

Adi AAAM. 2014. Buku ajar patologi veteriner sistemik: Sistema pernafasan. Denpasar: Swasta Nulus

Berata IK, Winaya IBO, Adi AAAM, Adnyana IBW. 2016. Buku ajar patologi umum veteriner uтит. Denpasar: Swasta Nulus

Bertone RE, Synder LA, Moore AS. 2002. Environmental tobacco smoke and risk of malignant lymphoma in pet cats. Am. J. Epidemiol. 155(3): 268-273. 
Bhattacharya S, Banerjee D, Bauri AK, Chattopadhyay S, Bandyopadhyay SK. 2007. Healing property of the piper betle phenol, allylpyrocatechol against indomethacininduced stomach ulceration and mechanism of action. World J. Gastroenterol. 13(27): 37053713.

Darjono T, Kurniasih C, Wasito R, Sutrisno B. 2001 Petunjuk praktikum patologi. Laboratorium Patologi Fakultas Kedokteran Hewan UGM, Yogyakarta.

Demedts IK, Demoor T, Bracke KR, Joss GF, Brussella GG. 2006. Role of apoptosis in the pathogenesis of copd and pulmonary emphysema. Respiratory Res. 27: 52.

Epler GR. 1992. Clinical overview of occupational lung disease. Radiol. Clin. North Am. 30(6): 1121-1133.

Fikriyah S, Febrijanto Y. 2012. Faktorfaktor yang mempengaruhi perilaku merokok pada mahasiswa laki-laki di asrama putra RS Baptis Kediri. $J$. Stikes. 5(1): 99-109.

Gilman AG, Hardman JG, Limbird LE. 1991. The pharmacological basis of therapeutics, $8^{\text {th }}$ Ed. New York, Pergamon Press.

Hasanah H. 2014. Baby smoker: Perilaku konsumsi rokok pada anak dan strategi dakwahnya. SAWWA. 9(2): 253-274.

Herliansyah. 2001. Mengunyah halia menyah penyakit. J. Penelitian Malaysia. 12: 45-57.

Japardi I. 2002. Patogenesis stroke iskemik tromboemboli. USU Digital Library.

Kumar V, Cotran RS, Robbins SL. 2007. Buku ajar patologi. $7^{\text {th }}$ Ed. Jakarta, Penerbit Buku Kedokteran EGC.

Lawrence GS. 2004. Implikasi disfungsi endotel dan radikal bebas. Makasar: Unit Riset Vascular, Bagian Patologi, FK Unhas, RSUP Dr. Wahidin Sudirohusodo.

Majundar B, Chaundari SR, Roy A. 2002. Potent antiulcerogenic activity of ethanol extract of leaf Piper betle linn by antioxidative mechanism. Indian $J$. Clin. Biochem. 17(1): 49-57.
Marianti A. 2009. Aktifitas antioksidan jus tomat pada pencegahan kerusakan jaringan paru-paru mencit yang dipapar asap rokok. J. Biosaintifika. 1: 1-10.

Muliartha IKG, Sriwahyuni E, Yuliawati. 2009. Pemberian kombinasi vitamin C dan E peroral memperbaiki kerusakan hepar akibat paparan rokok kretek sub kronik. J. Ked. Brawijaya. 24: 24-25.

Packard RRS, Libby P. 2008. Inflammation in atherosclerosis: from vascular biology to biomarker discovery and risk prediction. J. Clin. Chem. 1(54): 24-38.

Palmans E, Vanacker NJ, Pauwels RA, Kips JC. 2002. Effect of age on allergen induced structural airway changes in brown norway rats. Am. J. Respir. Crit. Care. Med. 165: 1280-1284.

Papathanasiou G, Mamali A, Papafloratos S, Zerva E. 2014. Effects of smoking on cardiovascular function: The role of nicotine and carbon monoxide. Health Sci. J. 8(2): 274-290.

Patnaik P. 1992. A comprehensip guide to the hazardous properties chemical substances. $16^{\text {th }}$ Ed. New York, Van Nostrand Reinhold.

Roomans GM, Dragomir A, Vanthanouvong V, Wroblewski R. 2002. Effects of nicotine on intestinal and respiratory epithelium. $J$. Submicroscopic Cytol. Pathol. 34(4): 381-388.

Ross R. 1999. Atherosclerosis-An inflammatory disease. New England J. Med. 340: 115-126.

Sary L, Nuryani DD. 2014. Faktor interpersonal dengan niat berhenti merokok pada siswa perokok di Kota Bandar Lampung. Musyawarah Kerja Ikatan Ahli Kesehatan Masyarakat Indonesia. 13(1): 288-297.

Sianturi G.2003. Merokok dan Kesehatan. Available From: http://aguscoy.wordpress.com (Akses 21 Maret 2014).

Supartini N, Santoso DI, Kardjito T. 1995. Konsep baru patogenesis asma bronkial. J. Respir. Indo. 15: 156-162 
Squier CA, Brogden K.1991. Human oral mucosa: Development, structure and function. Oxford: Wiley-Blackwell. Pp. 19-41.

Triana N, Ilyas S, Hutahaean S. 2013. Gambaran histopatologis pulmo mencit jantan (Mus musculus L.) setelah dipapari rokok elektrik. USU Digital Library.
William M, Trtchounian A, Talbot P. 2010 Conventional and electronic cigarette (e-cigarette) have different smoking characteristics. Nicotine Tobacco Res. 12: 905-912.

World Health Organization (WHO). 2009. Report on the scientific basis of tobacco product regulation: $3^{\text {rd }}$ Report. Study Group on Tobacco Regulation. 